\title{
Anti-Trib2 Autoantibody in Narcolepsy as A Result of Hypocretin/Orexin Nerve Deciduation
}

\author{
Susumu Tanaka ${ }^{1,2 *}$, Hisao Yamada ${ }^{1}$ and Tohru Kodama ${ }^{2}$ \\ ${ }^{1}$ Department of Anatomy and Cell Science, Kansai Medical University, Japan \\ ${ }^{2}$ Sleep Disorders Project, Tokyo Metropolitan Institute of Medical Science, Japan

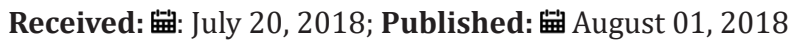

*Corresponding author: Susumu Tanaka, PhD, Department of Anatomy and Cell Science, Kansai Medical University, 2-5-1 Shinmachi, Hirakata-City, Osaka 573-1010, Japan

\section{Mini Review}

Narcolepsy is a disabling disorder characterized by recurrent daytime sleepiness and cataplexy [1]. The $90 \%$ to $95 \%$ loss of hypocretin (also called orexin) neurons in postmortem brains of narcolepsy is reported [2]. An immunological pathogenesis for the lack of hypocretin neurons in narcolepsy has been suggested in view of the tight association with the HLA-DQB1*0602 [3-4]. Recent findings including our research showed $16-26 \%$ of narcolepsy patients having anti-tribbles pseudokinase 2 (TRIB2) autoantibody in their blood [5-7]. However, it remains to be clarified whether or not causal relationship exists between anti-TRIB2 autoantibody and narcolepsy. TRIB2 is highly expressed not only in hypothalamic hypocretin neurons but also in visceral fat [8]. As one possibility, natural occurring antibody against TRIB2 might be induced without the injuring of hypocretin neurons, because anti-TRIB2 antibodies were more prevalent in HLA-DQB1*0602 positive narcolepsy cases with cataplexy compared with cases without HLA-DQB1*0602 [7]. HLA-DQB1*0602 might be key factor to produce such a natural occurring antibody which cross-reacts with TRIB2 antigens.
To test anti-TRIB2 autoantibody as the consequence of hypocretin cell destruction and release of its contents in the peripheral tissues, we examined if the anti-TRIB2 antibody titer changes following the loss of hypocretin neurons by using hypocretin/ataxin-3 transgenic (ataxin-3) mice, whose hypocretin neurons are postnatally ablated. No plasma obtained from young ataxin-3 mice before hypocretin neuron ablation (three and fourweek-old; seven females and five males), two (16.7\%) out of twelve 12 26-week-old ataxin-3 mice, and twelve (66.7\%) out of eighteen 28 38-week-old ataxin-3 mice were positive for anti-TRIB2 autoantibodies in ELISA experiment. The plasma positive for antiTRIB2 antibody on ELISA from over 26-week-old ataxin-3 mice, at the advanced stage of hypocretin cell destruction, also showed positive reactions against TRIB2 antigen in immunoblotting experiment, and this positive plasma specifically reacted with murine hypothalamic hypocretin neurons in immunofluorescence experiment.

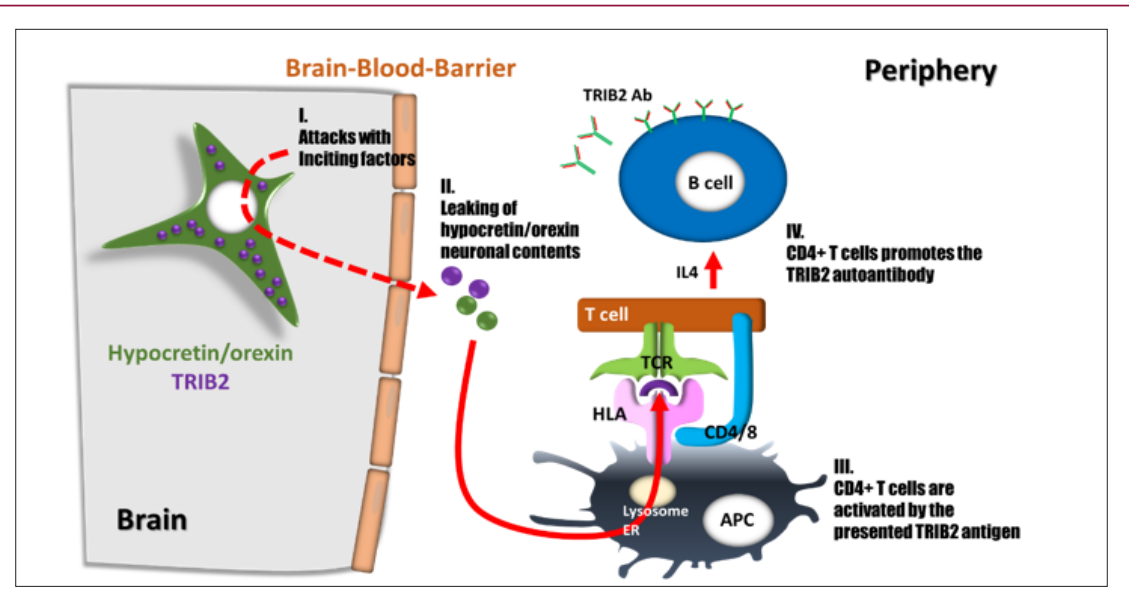

Figure 1:

I. Hypocretin/orexin neurons were attacked and destructed by unknown inciting factor(s).

II. Hypocretin/orexin neuron contents were released in the peripheral tissues.

III. CD4+ T cells recognizes the presented TRIB2 antigen and is activated.

IV. Activated CD4+ T cells stimulate CD8+ T cells and promotes anti-TRIB2 autoantibody production from B cells by using IL4. 
The latter releasing intracellular TRIB2 in peripheral might lead to the formation of autoantibodies. We conclude that antiTRIB2 autoantibody in narcolepsy patients is the consequence of hypocretin cell deciduation by unidentified factors [9] (Figure 1).

Interestingly, narcolepsy patients gain weight even as they eat considerably less than an average human being. Recent finding shows that hypocretin/orexin is critical for the formation of mature brown fat [10]. White adipocytes store calories while brown adipocytes burn them to generate heat. TRIB2 encodes the pseudokinase protein family that influences various biological processes including energy metabolism. Injection with orexin shows a substantial loss of fat. TRIB2 expression was associated with ectopic fat [8] and visceral fat accumulation [11]. Therefore TRIB2 autoantibodies might expedite to pack on the pounds in narcolepsy.

\section{References}

1. American Academy of Sleep Medicine. International Classification of SLEEP DISORDERS, 2nd ed, Diagnostic \& Coding Manual: Westchester, Illinois.

2. Nishino S, Ripley B, Overeem S, Lammers GJ, Mignot E (2000) Hypocretin (orexin) deficiency in human narcolepsy. Lancet 355(9197): 39-40.

3. Juji T, Satake M, Honda Y, Doi Y (1984) HLA antigens in Japanese patients with narcolepsy. All the patients were DR2 positive. Tissue antigens 24(5): 316-319.

ISSN: 2574-1241

DOI: 10.26717/BJSTR.2018.07.001516

Susumu Tanaka. Biomed J Sci \& Tech Res

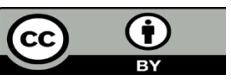

This work is licensed under Creative Commons Attribution 4.0 License

Submission Link: https://biomedres.us/submit-manuscript.php
4. Mignot E, Thorsby E (2001) Narcolepsy and the HLA system. The New England journal of medicine 344(9): 692.

5. Cvetkovic-Lopes V, Bayer L, Dorsaz S, Maret S, Pradervand S, et al. (2010) Elevated Tribbles homolog 2-specific antibody levels in narcolepsy patients. The Journal of clinical investigation 120(3): 713-719.

6. Toyoda H, Tanaka S, Miyagawa T, Honda Y, Tokunaga K, et al. (2010) AntiTribbles homolog 2 autoantibodies in Japanese patients with narcolepsy. Sleep 33(7): 875-878.

7. Kawashima M, Lin L, Tanaka S, Jennum P, Knudsen S, et al. (2010) AntiTribbles homolog 2 (TRIB2) autoantibodies in narcolepsy are associated with recent onset of cataplexy. Sleep 33(7): 869-874.

8. Nakayama K, Ogawa A, Miyashita H, Tabara Y, Igase M, et al. (2013) Positive natural selection of TRIB2, a novel gene that influences visceral fat accumulation, in East Asia. Human genetics 132(2): 201-217.

9. Tanaka S, Honda Y, Honda M, Yamada H, Honda K, et al. (2017) AntiTribbles Pseudokinase 2 (TRIB2)-Immunization Modulates Hypocretin/ Orexin Neuronal Functions. Sleep 40(1).

10. Sellayah D, Bharaj P, Sikder D (2011) Orexin is required for brown adipose tissue development, differentiation, and function. Cell metabolism 14(4): 478-490.

11. Fox CS, White CC, Lohman K, Heard-Costa N, Cohen P, et al. (2012) Genome-wide association of pericardial fat identifies a unique locus for ectopic fat. PLoS genetics 8: e1002705.

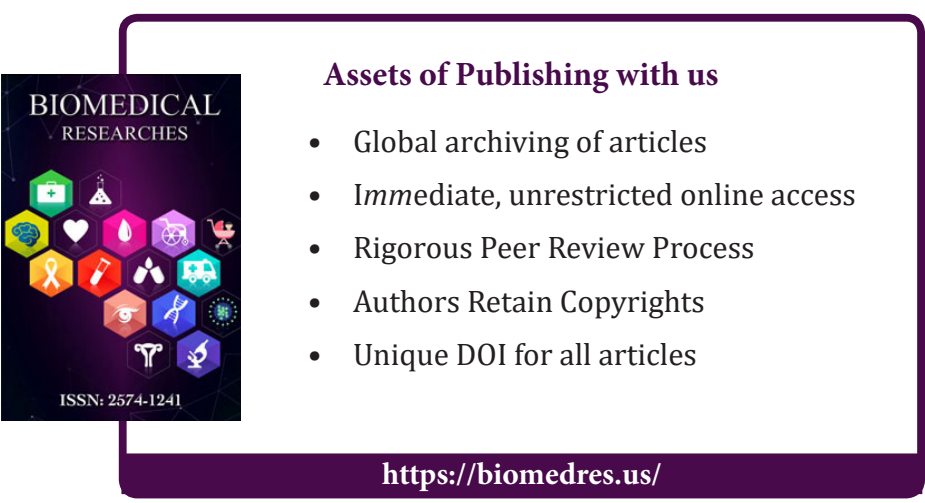

